Dental Therapist Journal

Vol. 3, No. 2, November 2021, pp. 58-65

P-ISSN 2715-3770, E-ISSN 2746-4539

Journal DOI: https://doi.org/10.31965/DTJ

Journal homepage: http://jurnal.poltekeskupang.ac.id/index.php/DTJ

\title{
Literature Review: Efektivitas Penggunaan Media Video Dalam Meningkatkan Pengetahuan Menyikat Gigi Yang Benar Pada Anak Sekolah Dasar
}

\author{
Claudiati $^{\mathrm{a}, 1^{\star}}$, Endang Purwaningsih ${ }^{\mathrm{a}}$, Siti Fitria Ulfah ${ }^{\mathrm{a}}$ \\ a Jurusan Kesehatan Gigi, Poltekkes Kemenkes Surabaya, Indonesia. \\ ${ }^{1}$ kfclau2@gmail.com* \\ *korespondensi penulis
}

\begin{tabular}{l}
\hline Informasi artikel \\
\hline Sejarah artikel: \\
Diterima 5 November 2021 \\
Disetujui 29 November 2021 \\
Dipublikasikan 30 November 2021 \\
\\
\hline Kata kunci: \\
Media video \\
Pengetahuan menyikat gigi \\
Anak sekolah
\end{tabular}

\begin{abstract}
ABSTRAK
Anak usia sekolah dasar masih memiliki proporsi terbesar masalah kesehatan gigi dan mulut, salah satunya yang disebabkan oleh rendahnya pengetahuan tentang menyikat gigi yang benar, pengetahuan dapat ditingkatkan melalui pembelajaran pendidikan kesehatan gigi termasuk khususnya media video. Penggunaan media video dinilai mampu meningkatkan pengetahuan menyikat gigi yang benar pada anak sekolah dasar karena mampu menampilkan gambar dan suara sehingga anak-anak menyukai. Tujuan Penelitian ini adalah untuk mengetahui efektivitas penggunaan media video dalam meningkatkan pengetahuan menyikat gigi yang benar pada anak sekolah dasar. Jenis penelitian ini adalah literature review. Pencarian jurnal dilakukan tahu 2015-2020 pada data base Google Scholar, DOAJ, PubMed dalam bahasa inggris dan indonesia Hasil penelitian ini adanya peningkatan pengetahuan siswa/i setelah dilakukan penyuluhan dengan media video dari kategori sedang menjadi kategori baik, sehingga penelitian menggunakan media video lebih efektif. Dapat disimpulkan bahwa penggunaan media video efektif untuk meningkatkan pengetahuan menyikat gigi yang benar pada anak sekolah dasar.
\end{abstract}

Keyword:

Videos Media

Knowledge of brushing teeth

school children

\section{ABSTRACT}

Literature Review: The Effectiveness of Using Video Media in Increasing Knowledge of Correct Tooth Brushing in Elementary School Children. Elementary school-age children still have the largest proportion of dental and oral health problems, one of which is caused by low knowledge about proper tooth brushing, knowledge can be increased through dental health education learning, including especially video media. The use of video media is considered to be able to increase the knowledge of correct brushing of teeth in elementary school children because it is able to display images and sounds so that children like it. The purpose of this study was to determine the effectiveness of using video media in increasing the knowledge of proper brushing of teeth in elementary school children. This type of research is a literature review. The search for journals was carried out in 2015-2020 on the Google Scholar, DOAJ, PubMed database in English and Indonesian. The results of this study showed an increase in student's knowledge after counseling with video media from the medium category to the good category so that research using video media was more effective. It can be concluded that the use of video 
media is effective in increasing the knowledge of correct brushing of teeth in elementary school children.

Copyright@ 2021 Dental Therapist Journal.

\section{PENDAHULUAN}

Anak usia sekolah dasar masih memiliki proporsi terbesar masalah kesehatan gigi dan mulut, salah satunya yang disebabkan oleh rendahnya pengetahuan tentang menyikat gigi yang benar (Astiti \& Fitriana, 2018). Menurut data RISKESDAS 2018 sebanyak 57,6\% penduduk Indonesia bermasalah gigi dan mulut, tetapi hanya 10,2\% yang mendapat perawatan oleh tenaga medis gigi. Berdasarkan kelompok usia 5-9 tahun, proporsi terbesar dengan masalah gigi dan mulut pada anak adalah (67,3\%) dengan $14,6 \%$ telah mendapat perawatan oleh tenaga medis gigi. Mayoritas penduduk Indonesia $(94,7 \%)$ sudah memiliki perilaku menyikat gigi yang baik yaitu menyikat gigi setiap hari. Namun dari persentase tersebut hanya $2,8 \%$ yang menyikat gigi di waktu yang benar, yaitu minimal dua kali, sesudah makan pagi dan sebelum tidur (Kementerian Kesehatan Republik Indonesia, 2018).

Berdasarkan penelitian pada bulan Februari 2019 di SD Negeri 21 Pemecutan, melalui wawancara secara acak dengan 10 orang siswa kelas 1 saat ditanya tentang cara menggosok gigi sebanyak 6 orang $(60 \%)$ belum tahu cara menggosok gigi yang benar, saat ditanya tentang berapa kali menggosok gigi dalam sehari sebanyak 7 orang $(70 \%)$ siswa menggosok gigi 1 kali dalam sehari yaitu pada waktu pagi, dan dari hasil pemeriksaan gigi sebanyak 7 orang $(70 \%)$ mengalami karies dikarenakan kurangnya pengetahuan menyikat gigi yang benar (Nyoman, et al., 2019).

Pengetahuan dapat ditingkatkan melalui pembelajaran pendidikan kesehatan gigi termasuk khususnya media video. Penggunaan media video dinilai mampu meningkatkan pengetahuan menyikat gigi yang benar pada anak sekolah dasar karena mampu menampilkan gambar dan suara sehingga anak-anak menyukai (Mulyadi, et al., 2018). Penelitian ini bertujuan untuk mengetahui efektivitas penggunaan media video dalam meningkatkan pengetahuan menyikat gigi yang benar pada anak sekolah dasar.

\section{METODE PENELITIAN}

Penelitian yang digunakan adalah penelitian jenis Systematic Literature Review dengan membandingkan dan merangkum keseluruhan jurnal tentang penggunaan media video dalam meningkatkan pengetahuan menyikat gigi yang benar pada anak sekolah dasar. Protokol pemilihan jurnal pada Systematic Literature Review menggunakan PRISMA checklist.

Literature didapatkan dari Google Scholar, DOAJ, PubMed. Jumlah artikel minimal yang direncanakan adalah 10 artikel, yang diterbitkan dalam 5 tahun terakhir. Pencarian jurnal menggunakan kata kunci Video media, dental brushing knowledge AND OR Elementary school children (Media Video, Pengetahuan Menyikat Gigi Dan Anak Sekolah).

Pencarian jurnal menggunakan kata kunci dengan metode" Boolean searching", yaitu: (Effectiveness or Efektivitas ) AND (Video media OR Media Video) AND "The correct dental brushing knowledge" AND (Private School children OR Elementary school children) .

Tabel 1. Kriteria inklusi dan eksklusi.

\begin{tabular}{llll}
\hline Kriteria & Inklusi & Eksklusi & \\
\hline Population/ Masalah & Anak sekolah dasar & Selain anak sekolah dasar \\
Intervention & Penelitian dengan & Penelitan dengan mengunakan \\
& menggunakan & interverensi selain penggunaan \\
intervensi & media video & \\
penggunaan & & \\
media video & - & \\
comparation & - & & \\
\hline
\end{tabular}




\begin{tabular}{|c|c|c|}
\hline Outcome & $\begin{array}{l}\text { Penggunaan media } \\
\text { video dalam } \\
\text { meningkatkan } \\
\text { pengetahuan } \\
\text { menyikat gigi yang } \\
\text { benar pada anak } \\
\text { sekolah dasar }\end{array}$ & $\begin{array}{l}\text { Selain Penggunaan media video } \\
\text { dalam meningkatkan pengetahuan } \\
\text { menyikat gigi yang benar pada anak } \\
\text { sekolah dasar }\end{array}$ \\
\hline $\begin{array}{l}\text { Study Design and Population } \\
\text { Type }\end{array}$ & $\begin{array}{l}\text { Deskriptif Analisa, } \\
\text { one group pretest- } \\
\text { posttest design }\end{array}$ & \multirow[t]{2}{*}{$\begin{array}{l}\text { Non Deskriptif Analisa, Non one } \\
\text { group pretest-posttest design, Non } \\
\text { Original Articel }\end{array}$} \\
\hline & $\begin{array}{l}\text { Type: } \quad \text { original } \\
\text { article }\end{array}$ & \\
\hline Tahun terbit & \multirow{2}{*}{$\begin{array}{l}2015-2020 \\
\text { Bahasa Indonesia } \\
\text { dan Bahasa Inggris }\end{array}$} & Sebelum 2015 \\
\hline Bahasa & & $\begin{array}{l}\text { Selain bahasa Indonesia dan bahasa } \\
\text { inggris }\end{array}$ \\
\hline
\end{tabular}

PRISMA flow diagram dalam pemilihan kelayakan artikel tentang efektivitas penggunaan media video dalam meningkatkan pengetahuan menyikat gigi yang benar pada anak sekolah dasar selanjutnya dilakukan skrining untuk memeriksa adanya duplikasi artikel dan kecocokan dari kata kunci dengan metode "Boolean Searching", sehingga didapatkan 452 judul artikel dalam 3 database yang tidak sesuai dengan judul. Dengan demikian, jumlah artikel yang lolos dalam skrining duplikasi adalah 67 artikel. Tahap selanjutnya adalah identifikasi dan penyaringan abstrak identifikasi dan penyaringan abstrak dilakukan menggunakan kriteria inklusi dan eksklusi berdasarkan PICOS, sehingga 50 artikel dikeluarkan dan ditemukan 23 artikel yang termasuk dalam PICOS. Tahap berikutnya adalah melakukan pengujian kelayakan dengan penilaian isi artikel secara lengkap, dengan cara yang sama dengan penilaian abstrak. Pada tahap ini harus dikeluarkan 13 artikel, sehingga yang masuk studi lebih lanjut yaitu sebanyak 10 artikel.

\section{HASIL DAN PEMBAHASAN}

Hasil literature review karakteristik media video dalam meningkatkan pengetahuan menyikat gigi anak sekolah dasar dan perubahan pengetahuan setelah penggunaan media video didapatkan dari 10 jurnal yang telah dinilai kelayakannya, selanjutnya dapat dilihat perbandingan hasil dari uji kelayakannya dari media video.

Tabel 2. Karakteristik media video dalam meningkatkan pengetahuan menyikat gigi.

\begin{tabular}{|c|c|}
\hline Media & $\begin{array}{l}\text { Karakteristik media video } \\
\text { pada artikel }\end{array}$ \\
\hline Video animasi kartun & $\begin{array}{l}\text { 1. Dapat memperjelas apa 1. Saragih, (2018) } \\
\text { yang ditayangkan dan 2. Andriany, et al., (2016) } \\
\text { lebih mudah ditangkap 3. Yanti, et al., (2015) } \\
\text { serta diingat karena } \\
\text { media animasi yang } \\
\text { dilengkapi suara dan } \\
\text { gambar. } \\
\text { 2. media penyuluhan } \\
\text { kartun animasi mampu } \\
\text { merangsang rasa ingin } \\
\text { tahu anak dan rasa } \\
\text { ketertarikan. memenuhi } \\
\text { 3. Dapat antuk } \\
\text { seseorang ang } \\
\text { menyimpan 90\% apa } \\
\text { yang dia baca, dengar, } \\
\text { lihat, dan sebut. }\end{array}$ \\
\hline
\end{tabular}




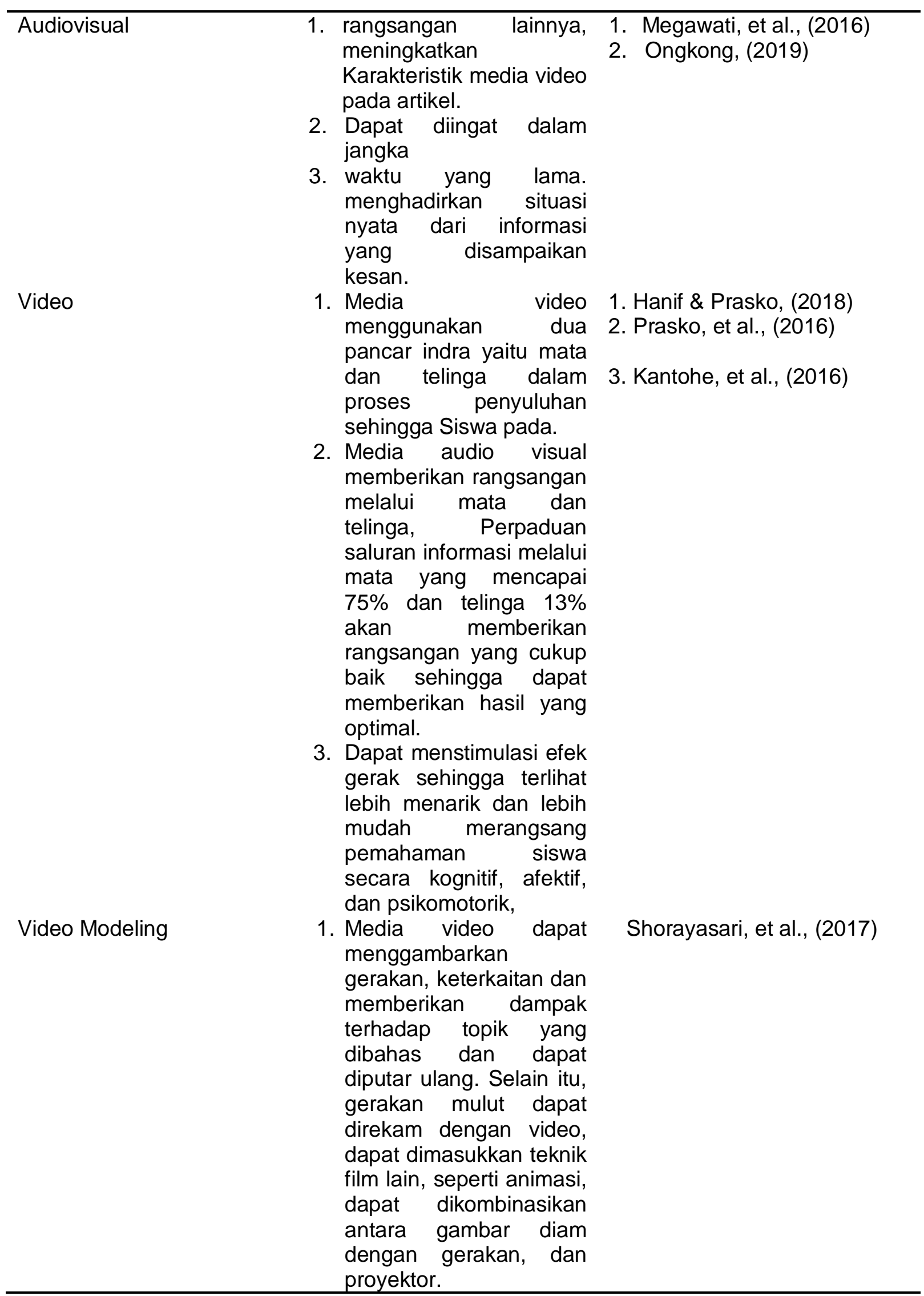

Media video mempunyai karakteristik yang sama mampu menyajikan gambar gerak, suara, kata-kata dan mempengaruhi 2 panca indra yaitu indra penglihatan dan pendengaran sehingga mampu merangsang rasa ingin tahu anak dan rasa ketertarikan. Hal ini didukung 
oleh penelitian (Kantohe, et al., 2016) media video dalam pembelajaran dapat memberikan pengalaman belajar yang lebih lengkap, jelas, variatif, menarik serta menyenangkan. 8 Media video termasuk dalam media pendidikan elektronik yang mempunyai kelebihan seperti mengikutsertakan banyak panca indera sehingga lebih mudah dipahami, lebih menarik karena ada suara dan gambar bergerak, bertatap muka, penyajian dapat dikendalikan, jangkauan relatif lebih besar, dan sebagai alat diskusi dan dapat diulang-ulang.

Tabel 3. Perubahan pengetahuan setelah penggunaan media video.

\begin{tabular}{|c|c|c|}
\hline Media video & $\begin{array}{l}\text { Perubahan Pengetahuan sebelum } \\
\text { dan sesudah }\end{array}$ & Artikel terkait \\
\hline Animasi kartun & $\begin{array}{l}1 \text { (a) Sebelum: kategori baik (0\%), } \\
25 \text { siswa dengan kategori } \\
\text { sedang (83,33\%) dan } 5 \text { siswa } \\
\text { dengan kategori buruk } \\
(16,67 \%) \\
\text { (b) Sesudah: } 27 \text { siswa dengan } \\
\text { kategori baik }(90 \%), 3 \text { siswa } \\
\text { dengan kategori sedang } \\
(10 \%) \text { dan tidak ada siswa } \\
\text { dengan kategori buruk (0\%). } \\
2 \text { (a) Sebelum : sebelum diberikan } \\
\text { media penyuluhan kartun } \\
\text { animasi menunjukkan } 47,6 \% \\
\text { kategori cukup. } \\
\text { (b) Sesudah: setelah diberikan } \\
\text { media penyuluhan } 81 \% \\
\text { dengan kategori baik } \\
3 \text { (a) Sebelum: hasil sebelum } \\
\text { dilakukan Perubahan } \\
\text { Pengetahuan sebelum dan } \\
\text { sesudah penyuluhan } 12,29 \\
\text { (b) Sesudah: Hasil sesudah } \\
\text { dilakukan penyuluhan } 30,72 \text {. }\end{array}$ & $\begin{array}{l}\text { 1. Saragih, (2018) } \\
\text { 2. Andriany, et al., } \\
\text { (2016) }\end{array}$ \\
\hline Audiovisual & $\begin{array}{l}1 \text { (a) Hasil sebelum dilakukan } \\
\text { penyuluhan menggunakan } \\
\text { audiovisual: } 59 \text { siswa (48,8\%). } \\
\text { Pada kategori kurang } \\
\text { berjumlah } 0 \text { siswa, kategori } \\
\text { cukup berjumlah } 4 \text { siswa } \\
(3,3 \%) \text { dan kategori baik } \\
\text { sekali berjumlah } 58 \text { siswa } \\
(47,9 \%) \text {. } \\
\text { (b) Hasil sesudah dilakukan } \\
\text { penyuluhan menggunakan } \\
\text { audiovisual: } 4 \text { siswa (3,3\%) } \\
\text { dan pengetahuan baik sekali } \\
\text { sebesar } 117 \text { siswa ( } 96,7 \%) \text {, } \\
\text { dengan kategorik baik sekali. } \\
2 \text { (a) Dari } 45 \text { responden } 4 \\
\text { responden (8.9\%), pada } \\
\text { kategori cukup sebanyak } 25 \\
\text { responden (55.6\%), dan pada } \\
\text { kategori kurang sebanyak } 16 \\
\text { responden (35.6\%). } \\
\text { (b) Sesudah diberikan tayangan } \\
\text { Audio Visual sebanyak } 32\end{array}$ & Megawati, et al., (2016) \\
\hline
\end{tabular}


responden (71.1\%) pada

kategori cukup sebanyak 13 responden $(28.9 \%)$, dan pada kategori kurang nol (0\%).

3. 16 anak yang berpengetahuan sedang menjadi 13 dan dari 6 menjadi 9 anak yang berpengetahuan tinggi.

Video dan flip chart

Video dan boneka tangan

Video dan demonstrasi

Video modeling
Hasil sebelum dilakukan penyuluhan menggunakan media video yaitu 90,78 dan sesudah dilakukan penyuluhan menggunakan media video 38,12 dengan kategorik sedang.

Sebelum dilakukan menggunakan media flip chart 86,25 dan hasil pengetahuan sesudah dilakukan penyuluhan menggunakan media flip chart 26,88 dengan kategori sedang.

Hasil skor pengetahuan sebelum dilakukan penyuluhan menggunakan media video 8,35 dan sebelum dilakukan penyuluhan menggunakan media boneka tangan sebesar 8,07 hasil pengetahuan sesudah di berikan penyuluhan menggunakan media video16,47 dan hasil nilai menggunakan media boneka tangan yaitu 15,53.

Hasil pengetahuan sebelum dilakukan penyuluhan dengan demonstrasi kategori sedang 12 orang (60\%), dan yang paling kecil adalah kategori baik (0\%), dan dengan audio visual keadaan responden dengan proporsi paling besar adalah pengetahuan dengan kategori sedang 15 orang (75\%), dan yang paling kecil adalah kategori baik $(0 \%)$.

Hasil pengetahuan sesudah diberikan penyuluhan dengan media demonstrasi menunjukkan bahwa proporsi paling besar adalah kategori sedang 15 orang (75\%), dan yang paling kecil adalah kategori kurang (0\%), dan hasil media video dengan kategori sedang 12 orang $(60 \%)$, dan paling kecil adalah kategori kurang $(0 \%)$.
Kantohe, et al., (2016)

Hanif \& Prasko, (2018)

Prasko, et al., (2016)

Hasil pengetahuan sebelum Shorayasari, et al., dilakukan penyuluhan menunjukkan (2017) 
nilai median adalah 52,50 rerata

nilai adalah 50,84 dengan standar

deviasi 10,408 dengan kategori

kurang. Sesudah diberikan

penyuluhan hasil pengetahuan nilai

median adalah 90,00 sedangkan

nilai rerata setelah diberikan

pendidikan kesehatan adalah 89,22

dengan 8,241 , baik.

\begin{abstract}
Perubahan pengetahuan penggunaan media video menunjukkan bahwa media video mampu meningkatkan pengetahuan anak sekolah dasar dibandingkan dengan media lainnya, artikel tersebut didukung oleh hasil penelitian dari (Luhulima et al., 2017). Video karakter animasi untuk anak sekolah sangat baik dan layak untuk membantu memahami materi yang diajarkan dibandingkan dengan media lainnya.

Berdasarkan penelitian (Prasko, et al., 2016), menunjukkan hasil yang berbeda yaitu media audiovisual bisa dikatakan efektif dalam meningkatkan pengetahuan anak sekolah dasar saat melakukan penyuluhan tetapi media audiovisual dibandingkan dengan demonstrasi menunjukkan lebih efektif menggunakan demonstrasi dikarenakan langsung melakukan pendekatan kepada sasaran sehingga demonstrasi mempunyai kelebihan proses penerimaan sasaran terhadap materi penyuluhan akan lebih berkesan secara mendalam sehingga membentuk pengertian dengan baik dan sempurna, terlebih bila peserta ikut serta secara aktif.
\end{abstract}

\title{
KESIMPULAN
}

Media video dapat digunakan sebagai media penyuluhan kesehatan gigi dan mulut karena media video memiliki banyak kelebihan. Terlihat ada peningkatan pengetahuan pada anak sekolah dasar setelah penggunaan media video dibandingkan dengan hasil sebelumnya karena pada umumnya media video dapat menampilkan gambar gerak dan mengeluarkan suara sehingga dapat menarik perhatian anak sekolah dan lebih mudah diterima karena mengaitkan langsung dengan indra penglihatan dan pendengaran. Disimpulkan bahwa penggunaan media video efektif untuk meningkatkan pengetahuan menyikat gigi yang benar pada anak sekolah dasar.

\section{DAFTAR PUSTAKA}

Andriany, P., Novita, C. F., \& Aqmaliya, S. (2016). Perbandingan Efektifitas Media Penyuluhan Poster Dan Videokartun Animasi Terhadap Pengetahuankesehatan Gigi Dan Mulut (Studi Pada Siswa/I Kelas V Sdn 24 Kota Banda Aceh). Journal Of Syiah Kuala Dentistry Society, 1(1), 65-72.

Astiti, N. K., \& Fitriana, L. B. (2018). Menggosok Gigi Dengan Video Pembelajaran Pada Anak. Jurnal Kepeyarawatan Respati Yogtakarta, 5(2), 378-382.

Hanif, F., \& Prasko, P. (2018). Perbedaan Pengaruh Penyuluhan Mengunakan Media Video dan Boneka Tangan Terhadap Peningkatan Pengetahuan Kesehatan Gigi dan Mulut Pada Siswa Sekolah Dasar. Jurnal Kesehatan Gigi, 5(2), 1. https://doi.org/10.31983/jkg.v5i2.3854

Kantohe, Z. R., Wowor, V. N., \& Gunawan, P. N. (2016). Perbandingan efektivitas pendidikan kesehatan gigi menggunakan media video dan flip chart terhadap peningkatan pengetahuan kesehatan gigi dan mulut anak. E-GIGI, 4(2), 7-12.

Kementerian Kesehatan Republik Indonesia. (2018). Hasil Utama Riskesdas 2018 Jakarta: Kementerian Kesehatan Republik Indonesia.

Luhulima, D., Degeng, I. N., \& Ulfa, S. (2017). Pengembangan Video Pembelajaran Karakter Mengampuni Berbasis Animasi untuk Anak Sekolah Minggu. Jurnal Inovasi Dan Teknologi Pembelajaran, 3(2), 110-120.

Megawati, R. R., Hartati, E., \& Supriyono, M. (2016). Efektifitas Pendidikan Kesehatan dengan Media Audiovisual Oleh Peer Group Terhadap Pengetahuan Menggosok Gigi Kelas 4 Dan 5 Di SDN Kalicari 01 Semarang. Jurnal IImu Keperawatan Dan Kebidanan (JIKK), $1(1), 1-11$.

Mulyadi, M. I., Warjiman., \& Chrisnawati. (2018). Efektivitas Pendidikan Kesehatan Dengan Media Video Terhadap Tingkat Pengetahuan Perilaku Hidup Bersih Dan Sehat. Jurnal 
Keperawatan STIKES Suaka Insan, 3(2), 1-9.

Nyoman, N., Puspita, R., Purwanti, I. S., \& Juanamasta, I. G. (2019). Edukasi Film Terhadap Perilaku Menggosok Gigi Pada Anak Usia 6 - 8 Tahun The Film Education On The Behavior Of Brushing Teeth For Children Aged 6 - 8 Years. Jurnal Kesehatan Masyarakat, 9(2), 152-158.

Ongkong, B. (2019). Perbedaan Sebelum dan Sesudah Di Berikan Pendidikan Kesehatan Dengan Metode Audio Visual Terhadap Pengetahuan Siswa/l Kelas 2 Tentang Menggosok Gigi Di SDN Serpong 2 Tahun 2016. Prosiding Seminar Nasional Humanis, 1(1), 93-99. http://openjournal.unpam.ac.id/index.php/Proceedings/article/view/5510

Prasko, P., Sutomo, B., Santoso, B., \& Jurusan Keperawatan Gigi Poltekkes Kemenkes Semarang, D. (2016). Penyuluhan Metode Audio Visual Dan Demonstrasi Terhadap Pengetahuan Menyikat Gigi Pada Anak Sekolah Dasar method of demonstration and audio visual, knowledge of brushing teeth. Jurnal Kesehatan Gigi, 3(2), 53-57.

Shorayasari, S., Effendi, D. P., \& Puspita, S. (2017). Perbedaan Pengetahuan Setelah Diberikan Pendidikan Kesehatan Tentang Menggosok Gigi Dengan Video Modeling. Jurnal IImu Kesehatan Masyarakat, 8(43-48), 43-48.

Saragih, A. Y. (2018). Pengaruh Penyuluhan Dengan Media Animasi Kartun Terhadap Tingkat Pengetahuan Tentang Menyikat Gigi Pada Siswa/l Kelas Iv-B Sd Negeri 104219 Tanjung Anom Kec. Pancur Batu Apri. 53(9), 1689-1699.

Yanti, G. N., Raphaelli, S., \& Natamihardja, L. (2015). Perbedaan Peningkatan Pengetahuan Antara Metode Ceramah dan Pemutaran Video Kartun Dalam Penyuluhan Kesehatan Gigi Pada Siswa Kelas II SD Bodhicitta Medan. Dentika Dental Journal,17(1), 10-13. https://jurnal.usu.ac.id/index.php/dentika/article/view/3149/1527 